\title{
HydroViz: design and evaluation of a Web-based tool for improving hydrology education
}

\author{
E. Habib ${ }^{1}$, Y. Ma ${ }^{2}$, D. Williams ${ }^{2}$, H. O. Sharif ${ }^{3}$, and F. Hossain ${ }^{4}$ \\ ${ }^{1}$ Department of Civil Engineering, University of Louisiana at Lafayette, P.O. Box 42991, Lafayette, LA, 70504, USA \\ ${ }^{2}$ Center for Innovative Learning and Assessment Technologies (CILAT), University of Louisiana at Lafayette, \\ P.O. Box 42051, Lafayette, USA \\ ${ }^{3}$ Department of Civil \& Environmental Engineering, University of Texas at San Antonio, San Antonio, USA \\ ${ }^{4}$ Department of Civil \& Environmental Engineering, Tennessee Technological University, Cookeville, Tennessee, USA
}

Correspondence to: E. Habib (habib@louisiana.edu)

Received: 31 January 2012 - Published in Hydrol. Earth Syst. Sci. Discuss.: 28 February 2012

Revised: 9 August 2012 - Accepted: 10 August 2012 - Published: 24 October 2012

\begin{abstract}
HydroViz is a Web-based, student-centered, educational tool designed to support active learning in the field of Engineering Hydrology. The design of HydroViz is guided by a learning model that is based on learning with data and simulations, using real-world natural hydrologic systems to convey theoretical concepts, and using Web-based technologies for dissemination of the hydrologic education developments. This model, while being used in a hydrologic education context, can be adapted in other engineering educational settings. HydroViz leverages the free Google Earth resources to enable presentation of geospatial data layers and embed them in web pages that have the same look and feel of Google Earth. These design features significantly facilitate the dissemination and adoption of HydroViz by any interested educational institutions regardless of their access to data or computer models. To facilitate classroom usage, HydroViz is populated with a set of course modules that can be used incrementally within different stages of an engineering hydrology curriculum. A pilot evaluation study was conducted to determine the effectiveness of the HydroViz tool in delivering its educational content, to examine the buy-in of the program by faculty and students, and to identify specific project components that need to be further pursued and improved. A total of 182 students from seven freshmen and senior-level undergraduate classes in three universities participated in the study. HydroViz was effective in facilitating students' learning and understanding of hydrologic concepts and increasing related skills. Students had positive perceptions of various features of HydroViz and they believe that
\end{abstract}

HydroViz fits well in the curriculum. In general, HydroViz tend to be more effective with students in senior-level classes than students in freshmen classes. Lessons gained from this pilot study provide guidance for future adaptation and expansion studies to scale-up the application and utility of HydroViz and other similar systems into various hydrology and water-resource engineering curriculum settings. The paper presents a set of design principles that contribute to the development of other active hydrology educational systems.

\section{Introduction}

Hydrology education relies mainly on engineering programs as the main academic base for the majority of those who specialize in hydrology (Wagener et al., 2007). However, most engineering hydrology courses focus largely on empirical approaches and lack necessary emphasis on understanding of basic hydrologic processes and learning from field data and new observational and simulation resources. As such, the hydrologic research community has expressed the need for fundamental improvements in current practices of hydrologic education, especially at the undergraduate level (Bourget, 2006; Wagener et al., 2007; Howe, 2008; Loucks, 2008; Ledley et al., 2008; CUAHSI, 2010; Ngambeki et al., 2012).

Early reports by the International Association of Hydrological Sciences (IAHS) panel on hydrological education (Nash et al., 1990) and the National Research Council (NRC, 1991) stressed the central role of observations in the study of 
hydrology and recommended that universities should make a conscious effort to introduce experimental material into the courses. As discussed by McDonald (1993), deficiencies in field components will lead to several adverse effects on the quality of graduating students. Students will lack appreciation of spatial and temporal variability of hydrologic processes and variables, will have an excessive trust in results obtained from models, and will lack the ability to develop self-learning skills and intuitive understanding. However, providing students with field experience is usually hampered by inaccessibility to measurement sites and remote areas, high equipment costs, and class time constraints. It is also not possible to measure every hydrologic variable of interest. In fact, most hydrologic variables and processes exhibit significant levels of spatial variability and, therefore, are difficult to observe using a set of sensors that are often too limited in their spatial sampling density and coverage.

Hydrologic computer modeling and simulation techniques (Beven, 2001) can address some of these limitations. Within an educational framework, simulation models can provide students and educators with supportive environments for inquiry and discovery-based learning (de Jong and Van Joolingen, 1998; Seibert and Vis, 2012; AghaKouchak and Habib, 2010; AghaKouchak et al., 2012). However, it is well recognized that all hydrologic models, regardless of their degree of complexity, are subject to inherent limitations due to model assumptions and simplifications and lack of parameter identification. Therefore, the NRC report (NRC, 1991) emphasized the importance of integrating modeling with field data and other sources of hydrologic observations as a viable approach for enhancing undergraduate engineering hydrology courses (Merwade and Ruddell, 2012). More recently, two major science community initiatives (the Consortium for Universities for the Advancement of Hydrologic Science, Inc., and the Collaborative Large-Scale Engineering Analysis Network for Environmental Research, CLEANER) have stressed the critical role of observations and simulation models for reforming the future of hydrologic engineering education. They recommended the developments of "learning materials for all education levels, including courses, topical modules, laboratory exercises, and videos, that incorporate new research and encourage broad interest in environmental sciences" (CUAHSI, 2010). The desired reform of hydrologic education to facilitate the effective introduction of hydrologic field and modeling experiences is not a trivial task. Hydrology is usually taught in a single course in most engineering programs, and therefore instructors do not have enough time to teach modeling software or expose students to field instruments. On the other hand, a purely theoretical coverage of such topics can be uninteresting to today's engineering students who are better inspired by hands-on and engaging teaching methods. In response to such recommendations, the current study develops a pilot hydrologic learning tool referred to herein as HydroViz (http://hydroviz.cilat. org/hydro/) that attempts to address the desired reform in the field of hydrology education. The development of HydroViz targets three main goals: (1) facilitating students' learning of basic hydrologic concepts and related data analysis skills, (2) development of adaptable course modules, and (3) development of improved knowledge on how Web-based geospatial navigation and visualization techniques can improve undergraduate hydrology education.

\section{HydroViz learning model}

In developing the HydroViz tool, the current study proposes a learning model that builds on recent advances in hydrologic data, computer simulations and Web-based technologies to help address current shortcomings in undergraduate engineering hydrology curricula. This model can also be useful to other engineering or Earth science curricula. Figure 1 presents an overview of our design model that is built on the following technical and pedagogical concepts:

1. Learning with data and simulations: integration of hydrological and meteorological data (in-situ observations and data from remote-sensing and geographical information resources), with the capabilities of numerical modeling simulations of different rainfall-runoff processes, constitute a very powerful approach for learning in a field like hydrology or other geosciences and engineering disciplines. The main instructional approach is to teach students with tools, data, and models, instead of teaching them about processes and models from an abstract perspective.

2. Embedding technical contents within real-world hydrologic systems: the use of real-world actual hydrologic systems (e.g., a watershed or a river basin) will empower instructors' teaching and students' learning of hydrologic concepts and processes that are otherwise difficult to teach using idealized examples and traditional textbook-based methods. This instructional approach has its roots in well-established research on the effectiveness of case-based pedagogies (Dochy et al., 2003; Yadav and Beckerman, 2009; Gallucci, 2006), and needs to see mainstream implementation in hydrologic and geosciences education.

3. Using Web-based geospatial visualization technologies: recent advances in scientific visualization and Webbased interactive applications can help achieve the desired integration of field data and model simulations in hydrological education curricula. Interactive teaching methods that are based on the principles of active engagement and visualization can enhance students' learning by exploiting their visual senses and thus engaging their interests (Cunningham, 2005; McGrath and Brown, 2005; Libarkin and Brick, 2002; Ramasundaram et al., 2005). Freely accessible 3-D geospatial 


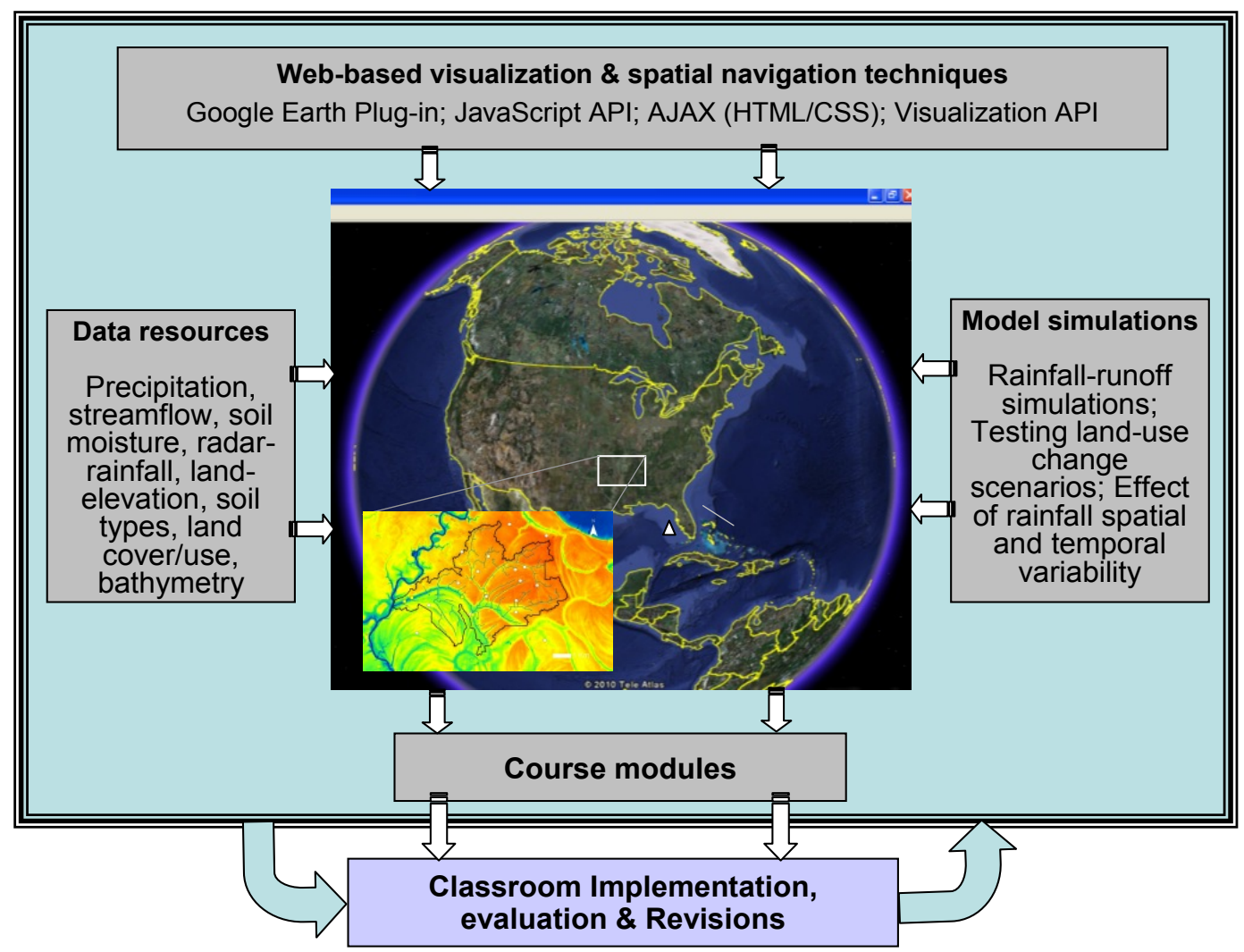

Fig. 1. Overall framework of the HydroViz system. A topographic map of the HydroViz watershed site in Lafayette, LA, is shown as a small insert.

navigation and data publishing resources are valuable tools that provide intuitive and realistic means for integration of real-world case studies into students' learning activities. The Web-based design provides ease of dissemination and transferability, which is a highly desirable feature of any new learning system.

While this model is designed for a certain engineering subject (hydrology) and a technical content (rainfall-runoff processes), its overall concepts and design elements are applicable to and can serve other engineering and Earth science curricula. In the current study, we present an application of this learning model to develop the HydroViz tool as an example of an active hydrological learning environment. Within this environment, students are presented with the overall technical and environmental context of the problem at hand, and at the same time confronted with the limitations in available data, analytical tools and simulation models. This environment allows for natural introduction of basic concepts, theories, and mathematical formulations, which can be quite effective, especially for today's students who are more engaged by hands-on teaching and a desire to contribute to solving real-world problems. In this paper, we will first describe the design of the tool. We discuss three aspects of the design: (1) the hydro-data and model simulation behind the tool, (2) the software design, and (3) the course modules embedded in the tool. Then we present the evaluation we conducted and discuss the findings and guidelines for future studies and projects. While the evaluation analysis performed here focused on developing guidelines that informed the improvement of HydroViz, this paper also provides knowledge to other hydrology education faculty on how to develop and implement similar tools to improve hydrology curriculum.

\section{Hydro-data and model simulations in HydroViz}

To facilitate students' learning through real-world applications, we developed the HydroViz tool for an actual hydrologic basin (the Isaac-Verot Watershed) (Fig. 2) located in the vicinity of the University of Louisiana at Lafayette campus. The watershed has an area of $35-\mathrm{km}^{2}$ and is a sub-drainage area of the Vermilion river basin, which drains into the Gulf of Mexico (Habib and Meselhe, 2006). The watershed is represented in HydroViz using different sets of information: insitu observations, geospatial datasets, remote-sensing data, and model simulations. The following sections provide brief descriptions of these sources of information. 


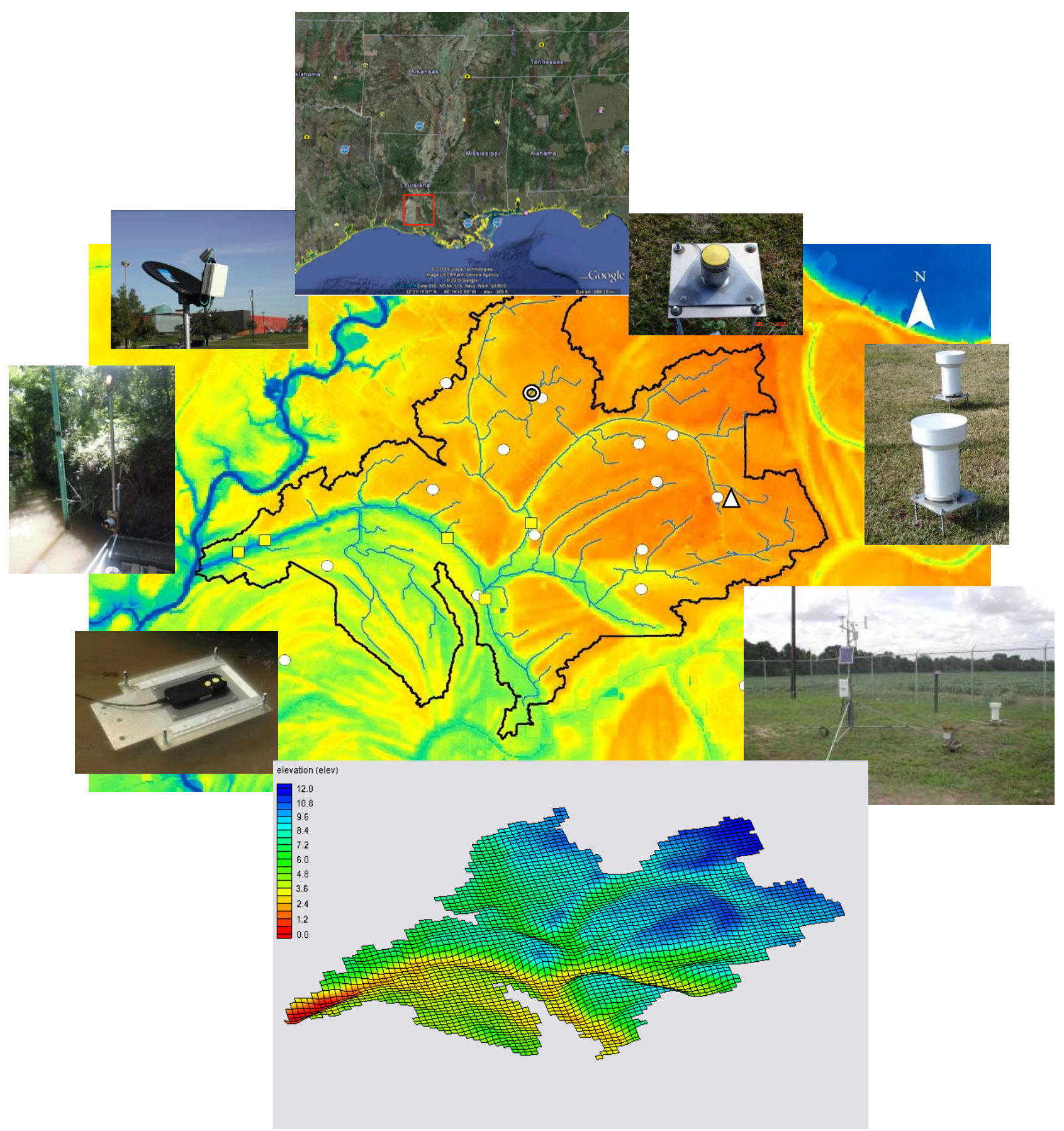

Fig. 2. Location map (upper panel) of the Isaac-Verot Experimental watershed used in the HydroViz tool. Central image: high-resolution topography of the watershed and the locations of sensors deployed in the watershed (surrounding images). The lower panel shows the 25-km computational grid used to develop the GSSHA hydrologic model for the watershed.

\subsection{Field instrumentation and in-situ data}

The in-situ data are available from a suite of hydrometeorological sensors that were deployed in the watershed through previous research efforts. These sensors included 13 tipping-bucket rain gauge stations, gauges, acoustic streamflow gauges at the watershed outlet and at four interior locations, a volumetric soil moisture sensor, and a total weather station. 


\subsection{Remote-sensing observations}

Besides in-situ rain gauges, HydroViz also includes rainfall information from two remote sensing techniques, radars and satellites. These data sources were included to introduce students to the wealth of information provided by weather radars and satellites in terms of the large spatial coverage and high temporal resolution. Radar-rainfall data over the watershed were acquired from the US National Weather Service (NWS) Stage IV dataset (Habib et al., 2009) which has a spatial resolution of $\sim 4 \times 4 \mathrm{~km}^{2}$ and is available every hour. The satellite-rainfall dataset in HydroViz was acquired from the global CMORPH product (Joyce et al., 2004) which has an approximate spatial resolution of $\sim 8 \times 8 \mathrm{~km}^{2}$ and a temporal frequency of 30-min.

\subsection{GIS data}

Geospatial data on topography and soil and vegetation types in the watershed were gathered and integrated into HydroViz. Elevation data were acquired from the US Geological Survey in three different resolutions: 1 arc-second $(\sim 30 \mathrm{~m})$ $1 / 3$ arc-second $(\sim 10 \mathrm{~m})$, and $1 / 9$ arc-second $(\sim 3 \mathrm{~m})$. The three resolutions allow students to understand the impact of data resolution on hydrologic analysis and predictions. Soil type data were gathered from the US Department of Agricultural based on two sources: the Soil Survey Geographic (SSURGO) database, and the State Soil Geographic (STATSGO) database. Land-Use and Land-Cover maps were acquired based on historical and more recent datasets from the US Geological Survey. Using historical and recent maps, students can investigate the effect of urbanization and landuse change on flooding in the watershed. Other datasets on stream hydrography were also embedded into the HydroViz tool to support a full description of the watershed.

\subsection{Numerical simulations}

The hydrologic simulation component of HydroViz is developed using the Gridded Surface Subsurface Hydrologic Analysis modeling system (GSSHA; Downer and Ogden, 2004). GSSHA is a physically based, distributed hydrologic model and allows for detailed representation of important rainfall-runoff processes in the watershed (e.g., rainfall distribution, overland water retention, infiltration, evapotranspiration, overland flow). A $25 \times 25 \mathrm{~m}^{2}$ Cartesian grid (Fig. 2) was used to represent the watershed topographic and hydrologic properties. A full description of the model setup, calibration and validation is available in Habib et al. (2008). A set of rainfall-runoff simulations and application scenarios were performed using the GSSHA model for an actual rainfall event, Tropical Storm Matthew, which swept across South Louisiana for several days (7-10 October 2004) and resulted in widespread flooding. HydroViz was populated with various simulation outputs in the form of streamflow time series at the watershed outlet and at interior locations, and time series of spatially distributed fields of overland runoff, water depth, infiltration rates, cumulative infiltrated water, and soil moisture.

\section{HydroViz software}

The design of the HydroViz software is driven by the following functionalities: Web accessibility, ease of dissemination, highly-visual and interactive capabilities and the ability to integrate the geospatial data and spatio-temporal model simulations. The intent is to provide authentic and handson inquiry-based activities that can improve students' learning. To fulfill these requirements, HydroViz was built as a browser-based, Web-accessible system that leverages the power of freely available geospatial and visualization resources. HydroViz employs the free Google Earth Plug-in and its JavaScript API to enable presentation of geospatial data layers and embed them in Web pages that have the same look and feel of Google Earth (see Fig. 3 and http://hydroviz.cilat.org/hydro/). This software design allows the user to run the tool on a typical desktop computer with Internet access after a free Google Earth Web browser plugin is installed. Embedding Google Earth in a Web-browser enhances the accessibility and dissemination. Within the HydroViz setting, students can use Google Earth navigation capabilities to explore the watershed and use the embedded inquiry-based investigations and the supporting layers of hydrologic information.

\section{Course modules in HydroViz}

To facilitate the introduction of HydroViz in classrooms, a total of 13 educational modules have been designed and embedded into HydroViz (Table 1). The modules range from basic activities (e.g., exploring watershed characteristics) to advanced analysis of field data and model simulations. Each module is self-contained and all instructions, guidance and technical questions are embedded within the same screens that show the watershed and its visual displays. These modules were designed using an actual rainfall event, Tropical Storm Matthew, which swept across South Louisiana for several days (7-10 October 2004). Table 1 provides a list of these modules; the reader is referred to the HydroViz Web page (http://hydroviz.cilat.org/hydro) for a full description of each module and the student activities embedded into it.

It is important to point out that HydroViz course modules are not designed to be a replacement of regular course material or activities. Instead, they can support subjects that the instructor covers in a typical hydrology class to emphasize concepts that are difficult to convey using traditional approaches, or to help introduce new subjects that are not typically covered. The modules are primarily designed for senior level courses within Civil and Environmental Engineering 


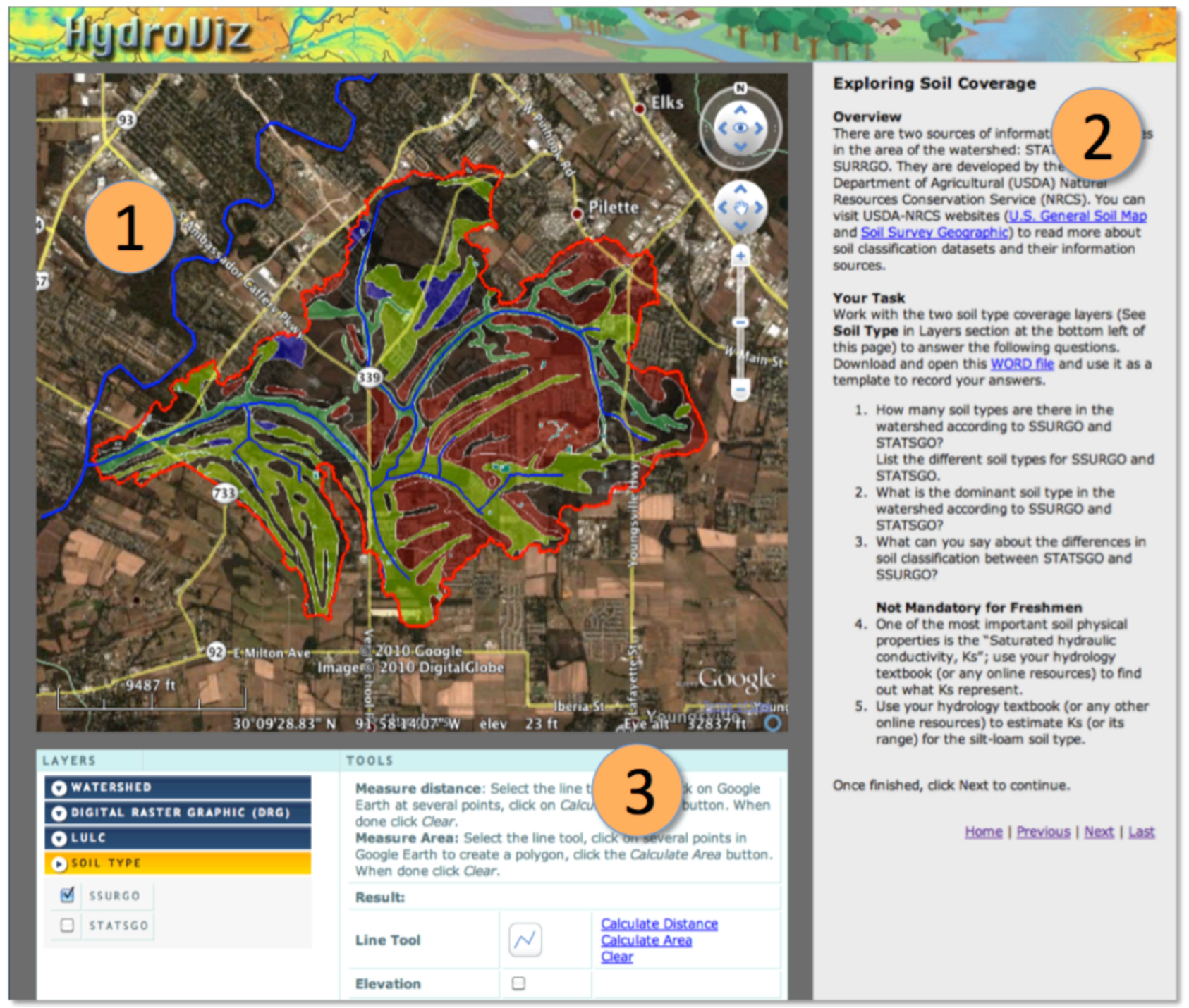

Fig. 3. HydroViz Interface showing: (1) Google Earth in the main display, (2) the educational content and educational tasks on the right side, and (3) layers and tools at the bottom of the interface.

curriculum. Selected modules can be used in freshmen-level civil engineering courses. Advanced modules in HydroViz can also be used in first-semester graduate courses. Table 1 indicates which curricular course level each module can be used in (first column in the table) and which topics/chapters in the course that each module can support (last column in the table). The modules can be introduced to the students at different stages within a single course, where each module can serve as an educational companion to the technical subject covered by the instructor. Instructors can choose from the modules based on their course syllabus. Each module starts with an introduction to the technical subject followed by a set of activities that the students need to complete. The activities are interactive and inquiry-based and include investigative tasks as well as quantitative and qualitative analyses.

\section{Implementation and evaluation of $\mathrm{HydroViz}$}

HydroViz has been implemented and evaluated in 7 undergraduate courses at the developing institution and two additional independent institutions (Tabl 2). The focus of the evaluation experiment was on two general aspects of the HydroViz tool: (1) to evaluate how effective the project idea and the tool design is in delivering the intended educational contents so that we can continue to pursue the developments in future, larger-scale developments, and (2) to inform the improvement of this and other similar projects. The results of this pilot evaluation will inform future expansion and enhancement of the HydroViz tool and lead to large-scale evaluation studies that focus on assessing the added gain in students' learning in comparison to other traditional hydrology education approaches. The following sections provide a 
Table 1. Summary of HydroViz course modules (see http://hydroviz.cilat.org/hydrofordetails). The first column indicates the possible target course levels (UG: Undergraduate Senior (S) or Freshmen (F), and G: Graduate). The last column lists possible subjects/chapters that can be supported by HydroViz modules.

\begin{tabular}{|c|c|c|c|}
\hline Module & Title & Brief description & Course subject/chapter \\
\hline $\begin{array}{l}\text { Module } 1 \\
\text { UG (F \& S) }\end{array}$ & $\begin{array}{l}\text { Getting acquainted } \\
\text { with the watershed }\end{array}$ & $\begin{array}{l}\text { Introductory session to familiarize students } \\
\text { with the watershed, its } \\
\text { geographical/physical characteristics. }\end{array}$ & $\begin{array}{l}\text { Watershed } \\
\text { concepts }\end{array}$ \\
\hline $\begin{array}{l}\text { Module } 2 \\
\text { UG (F \& S) }\end{array}$ & $\begin{array}{l}\text { Exploring Land-Use } \\
\text { Land-Cover (LULC) } \\
\text { Coverage map }\end{array}$ & $\begin{array}{l}\text { Students identify how many LULC classes } \\
\text { exist in the watershed, assess main changes } \\
\text { between recent/historical LULC }\end{array}$ & \multirow{3}{*}{$\begin{array}{l}\text { Watershed } \\
\text { characteristics/ } \\
\text { Hydrologic } \\
\text { Processes }\end{array}$} \\
\hline $\begin{array}{l}\text { Module } 3 \\
\text { UG (F \& S) }\end{array}$ & $\begin{array}{l}\text { Exploring soil } \\
\text { coverage }\end{array}$ & $\begin{array}{l}\text { Students perform analysis on soil } \\
\text { characteristics and estimate basic properties } \\
\text { that control watershed response }\end{array}$ & \\
\hline $\begin{array}{l}\text { Module } 4 \\
\text { UG (F \& S) }\end{array}$ & $\begin{array}{l}\text { Exploring land } \\
\text { elevation }\end{array}$ & $\begin{array}{l}\text { Students examine the watershed } \\
\text { topography and drainage patterns, examine } \\
\text { differences between different resolutions }\end{array}$ & \\
\hline $\begin{array}{l}\text { Module } 5 \\
\text { UG (F \& S) }\end{array}$ & $\begin{array}{l}\text { Exploring field } \\
\text { equipment }\end{array}$ & $\begin{array}{l}\text { Students explore hydro-meteorological } \\
\text { sensors; study their operation mechanism; } \\
\text { and download and analyze sample data }\end{array}$ & $\begin{array}{l}\text { Hydrologic } \\
\text { Measurements \& } \\
\text { Instrumentation }\end{array}$ \\
\hline $\begin{array}{l}\text { Module } 6 \\
\text { UG (S) }\end{array}$ & $\begin{array}{l}\text { Working with a } \\
\text { real rain storm }\end{array}$ & \multirow{2}{*}{$\begin{array}{l}\text { Students work with Tropical Storm } \\
\text { Matthew; read articles describing storm } \\
\text { impact; compare satellite images (prior and } \\
\text { post-storm) and identify flooded areas; } \\
\text { download and analyze in-situ rainfall data }\end{array}$} & $\begin{array}{l}\text { Hydrologic } \\
\text { Processes }\end{array}$ \\
\hline $\begin{array}{l}\text { Module } 7 \\
\text { UG }(S)\end{array}$ & $\begin{array}{l}\text { Analysis of rainfall } \\
\text { measurements }\end{array}$ & & $\begin{array}{l}\text { Hydrologic } \\
\text { Analysis }\end{array}$ \\
\hline $\begin{array}{l}\text { Module } 8 \\
\text { G }\end{array}$ & $\begin{array}{l}\text { Measuring rainfall } \\
\text { using remote sensing } \\
\text { techniques }\end{array}$ & $\begin{array}{l}\text { Students explore rainfall estimates from } \\
\text { satellites and radars; perform quantitative } \\
\text { analysis to compare satellite and radar } \\
\text { estimates versus ground rain gauges. }\end{array}$ & $\begin{array}{l}\text { Remote Sensing } \\
\text { of Rainfall }\end{array}$ \\
\hline $\begin{array}{l}\text { Module } 9 \\
\mathrm{UG}(\mathrm{S})\end{array}$ & $\begin{array}{l}\text { Analysis of streamflow } \\
\text { data during storm } \\
\text { Mathew }\end{array}$ & $\begin{array}{l}\text { Students examine streamflow observations } \\
\text { during Storm Mathew; estimate runoff } \\
\text { peaks, time-to-peak and total runoff } \\
\text { volume; runoff-rainfall ratios. }\end{array}$ & $\begin{array}{l}\text { Hydrologic } \\
\text { Analysis/ } \\
\text { Surface Runoff }\end{array}$ \\
\hline $\begin{array}{l}\text { Module } 10 \\
\text { UG }(S)\end{array}$ & $\begin{array}{l}\text { Runoff analysis using } \\
\text { Curve Number }\end{array}$ & \multirow{2}{*}{$\begin{array}{l}\text { Students apply the Curve Number (CN) } \\
\text { and TR methods to estimate runoff depth; } \\
\text { analyze effect of land-use scenarios and } \\
\text { antecedent moisture. }\end{array}$} & $\begin{array}{l}\text { Surface Runoff/ } \\
\text { Hydrologic }\end{array}$ \\
\hline $\begin{array}{l}\text { Module } 11 \\
\mathrm{UG}(\mathrm{S})\end{array}$ & $\begin{array}{l}\text { TR55 graphical } \\
\text { method }\end{array}$ & & $\begin{array}{l}\text { Design/ } \\
\text { Hydrology of } \\
\text { Small Catchments }\end{array}$ \\
\hline $\begin{array}{l}\text { Module } 12 \\
\mathrm{UG}(\mathrm{S}) \& \mathrm{G}\end{array}$ & $\begin{array}{l}\text { Setting up a hydrologic } \\
\text { model }\end{array}$ & $\begin{array}{l}\text { Introduce students to different steps on } \\
\text { building a distributed hydrologic model }\end{array}$ & $\begin{array}{l}\text { Introduction to } \\
\text { Hydrologic }\end{array}$ \\
\hline $\begin{array}{l}\text { Module } 13 \\
\text { UG }(S) \& G\end{array}$ & $\begin{array}{l}\text { Hydrologic model } \\
\text { simulations }\end{array}$ & $\begin{array}{l}\text { Students evaluate results of model } \\
\text { calibration/validation; visualize spatial } \\
\text { fields of model simulations of } \\
\text { rainfall-runoff processes }\end{array}$ & Modeling \\
\hline
\end{tabular}


Table 2. Information on classes participating in HydroViz evaluation.

\begin{tabular}{llllc}
\hline Course title & University & Level & Semester & $\begin{array}{c}\text { Number of } \\
\text { Participants }\end{array}$ \\
\hline $\begin{array}{l}\text { CIVE 101 Introduction } \\
\text { to Civil Engineering } \\
\text { CIVE 101 Introduction } \\
\text { to Civil Engineering } \\
\text { CIVE 429 Hydrology }\end{array}$ & $\begin{array}{l}\text { University of } \\
\text { Louisiana at } \\
\text { Lafayette }\end{array}$ & Freshmen & Spring 2010 & 20 \\
\hline $\begin{array}{l}\text { CEE 4420 Engineering } \\
\text { Hydrology }\end{array}$ & $\begin{array}{l}\text { Tennessee Tech } \\
\text { University }\end{array}$ & Senior & Fall 2010 & 38 \\
\hline $\begin{array}{l}\text { CE 1301 Introduction to } \\
\text { Civil Engineering }\end{array}$ & $\begin{array}{l}\text { University of Texas } \\
\text { at San Antonio }\end{array}$ & Freshmen & Spring 2010 & 29 \\
$\begin{array}{l}\text { Civil Engineering } \\
\text { CE 4603 Water }\end{array}$ & & Freshmen & Fall 2010 & 20 \\
\begin{tabular}{l} 
Resources Engineering \\
\hline
\end{tabular} & & Senior & Fall 2010 & 18 \\
\hline
\end{tabular}

detailed description of the methods and the data sources that were used in the HydroViz evaluation experiment.

\subsection{Evaluation methods}

Design-based research (Design-Based Research Collective, 2003) provided an overarching framework that supports the development and evaluation of HydroViz. Design-based research emphasizes the development of not only practical solutions to educational problems but also design principles that may inform other projects and contribute to the understanding of teaching and learning. HydroViz evaluation was both formative and summative. The summative aspect focused on project effectiveness in terms of overall student learning and perception. In order to improve the project in its current and future phases, the formative aspect of the evaluation examined the buy-in of the program by faculty and students and investigated the effectiveness of different modules and perceptions of program features (e.g., using Web interfaces and Google Earth plugin). The evaluation of HydroViz was informed by an improvement-focused evaluation model (Posavac and Carey, 2003). This model focuses on improving the program by identifying and addressing the issues early and continuously throughout the program. A mixed method research approach (Chatterji, 2005) guided our data collection. Quantitative survey data and homework assignments helped determine the success of the program in delivering the educational contents. Qualitative survey question and interviews helped explain why and how the software worked or failed to work in order to inform improvement.

\subsection{Evaluation questions}

The following evaluation questions guided the evaluation:

1. How effective is the conceptual design and software features of HydroViz in facilitating students' learning and delivering the embedded educational contents on hydrologic concepts and related skills?

2. What are students' perceptions of various features and characteristics of HydroViz?

3. What are students' perceptions of HydroViz as a part of the curriculum?

4. How effective is HydroViz in developing freshmen engineering students' interest in hydrology as a subject area?

5. Do students in different classes and universities differ in their learning of the hydrologic concepts and perceptions of HydroViz?

6. What can be done to improve HydroViz?

\subsection{Participants}

A total of 182 students and 6 instructors in three universities participated in the evaluation study over the course of two semesters (Table 2). The courses included two senior-level Engineering Hydrology classes, one senior-level Water Resources class, and four freshmen-level Introduction to Civil Engineering classes. 


\subsection{Data sources}

\subsubsection{Performance tasks in HydroViz}

Based on Wiggins and McTighe (1998), knowledge applications and performance tasks are important assessment methods for evaluation of student learning. Therefore, several of such tasks were designed and embedded into the HydroViz course modules. Each task was accompanied with a set of questions for which the students have to record their answers and observations based on the activities performed. The questions are primarily knowledge application and problem-solving tasks. At the end of each module, the students save their reports in template files furnished to them within HydroViz and submit them to the instructor. Students' reports submitted at the completion of the performance tasks were compiled and used to guide the evaluation analysis.

\subsubsection{Online surveys}

An online student survey was used to examine students' perceptions of the software. It is a 17-item, 5-point Likert scale instrument that presents 17 statements to students who can choose one of the following answers, "Strongly agree", "Agree", "Neither agree nor disagree", "Disagree", and "Strongly disagree". The survey includes six items on students' perceptions of whether the software contributed to their understanding of certain hydrologic concepts. For example, students were given the following statement "The HydroViz project contributed to my understanding of the concept of watersheds and sub-watersheds." For students in the senior level Engineering Hydrology class, the survey includes an item to examine their perception of whether HydroViz improved on current teaching tools/methods typically used in hydrologic engineering courses. For students in the freshmen level Introduction to Civil Engineering classes, there are two items that investigate their perception of whether the tool was useful in introducing basic hydrologic concepts and increasing their enthusiasm for the subject of hydrology. The survey instrument also includes seven items related to students' perceptions of various features and characteristics of HydroViz. In addition, the survey includes a question on whether the tool fits well with the curriculum and a text field for students to enter any additional comments that they may have.

\subsubsection{Informal interviews}

Notes from informal interviews with students in an Engineering Hydrology class serve as another data source. A list of questions was asked to examine students' perceptions of HydroViz. The interviews include discussions of issues and areas for improvements. The interviews were conducted as a follow-up to the survey to provide a means to triangulate the survey data (Miles and Huberman, 1994) and to understand why students answered the survey questions in a certain way.

\subsection{Data collection procedures}

HydroViz was introduced and evaluated in a total of seven undergraduate courses at three universities (Table 2). In each of these classes, the instructor first presented the HydroViz tool to the students. The presentation includes a brief introduction on how to install the Google Earth plug-in and how to navigate and use the tool. Students were required to complete the tasks embedded within each module in HydroViz and answer the questions and submit them as a homework assignment. In Spring of 2010, the HydroViz modules were assigned towards the end of the semester and the students were given a period of two weeks to complete the activities. In Fall 2010, the modules were assigned incrementally within the semester. The numbers of modules assigned to the students varied by course type and semester. In Table 3, blank cells indicate the modules that were not assigned to a class. In some classes (e.g., Tennessee Tech senior hydrology class), the instructor selected certain modules that overlapped with the course syllabus and used HydroViz to emphasize and evaluate students' learning of specific topics covered in the course. In other senior classes (e.g., University of Louisiana senior hydrology class), the instructor chose to cover all modules to introduce students to some topics that are not typically covered in the course. In the freshmen-level classes, instructors assigned several modules in the Spring 2010; but decided in the subsequent semester to assign only introductory modules, which are more appropriate for freshmen students. In some classes, the assignments contribute to the grades that students receive for the class. In some other classes, the assignments were not part of the grading structure for the course. Once students completed and submitted their assignments, they were also given an online survey to complete. Some of the participating professors also conducted informal interviews with students once they completed the assignment.

\section{Evaluation results}

\subsection{How effective is the conceptual design and software features of HydroViz in facilitating students' learning and delivering the embedded educational contents on hydrologic concepts and related skills?}

To answer this question, students' reports on the performance tasks in HydroViz were graded and used to calculate descriptive statistics (Tables 3-5). In addition, descriptive statistics were calculated for six survey items that ask students' perceptions of how well HydroViz contributed to their learning. If students score $90 \%$ on a certain task, we can argue that the design of the tool and the specific learning module(s) successfully facilitated students' learning of the hydrologic concepts and skills for which the task was designed. Table 3 shows that an average of $66-85 \%$ of the students scored $90 \%$ or higher on the different course modules in HydroViz. This 
Table 3. Percentages of students who received a $90 \%$ or higher score in the different HydroViz modules.

\begin{tabular}{|c|c|c|c|c|c|c|c|c|c|}
\hline & $\begin{array}{l}\text { Watersheds } \\
\text { and sub- } \\
\text { watersheds }\end{array}$ & $\begin{array}{l}\text { Land-Use } \\
\text { Land Cover }\end{array}$ & $\begin{array}{l}\text { Soil } \\
\text { type }\end{array}$ & $\begin{array}{c}\text { Land } \\
\text { elevation }\end{array}$ & $\begin{array}{c}\text { Field } \\
\text { equipment }\end{array}$ & $\begin{array}{c}\text { Rainfall } \\
\text { data }\end{array}$ & $\begin{array}{c}\text { Rainfall } \\
\text { measurement } \\
\text { analysis }\end{array}$ & $\begin{array}{l}\text { Measuring } \\
\text { rainfall } \\
\text { using } \\
\text { remote } \\
\text { sensing }\end{array}$ & $\begin{array}{l}\text { Analysis } \\
\text { of stream } \\
\text { flow data }\end{array}$ \\
\hline Overall average & $85 \%$ & $72 \%$ & $70 \%$ & $69 \%$ & $74 \%$ & $73 \%$ & $68 \%$ & $66 \%$ & $\mathrm{~N} / \mathrm{A}$ \\
\hline Senior class average & $82 \%$ & $77 \%$ & $69 \%$ & $72 \%$ & $78 \%$ & $91 \%$ & $85 \%$ & $87 \%$ & $69 \%$ \\
\hline Freshmen class average & $87 \%$ & $68 \%$ & $70 \%$ & $65 \%$ & $71 \%$ & $64 \%$ & $51 \%$ & $56 \%$ & N/A \\
\hline CIVE $429 \mathrm{SP}$ & $83 \%$ & $92 \%$ & $95 \%$ & $90 \%$ & $96 \%$ & $91 \%$ & $90 \%$ & $87 \%$ & $70 \%$ \\
\hline CE 4603 FA & $81 \%$ & $70 \%$ & $67 \%$ & $69 \%$ & N/A & N/A & N/A & N/A & N/A \\
\hline CEE 4420 FA & N/A & $69 \%$ & $44 \%$ & $57 \%$ & $59 \%$ & N/A & $79 \%$ & N/A & $68 \%$ \\
\hline CIVE $10 \mathrm{SP}$ & $81 \%$ & $63 \%$ & $65 \%$ & $57 \%$ & $59 \%$ & $57 \%$ & $46 \%$ & $51 \%$ & N/A \\
\hline CE $1301 \mathrm{SP}$ & $98 \%$ & $77 \%$ & $83 \%$ & $73 \%$ & $83 \%$ & $70 \%$ & $55 \%$ & $61 \%$ & N/A \\
\hline CIVE $101 \mathrm{FA}$ & $81 \%$ & $63 \%$ & $63 \%$ & N/A & N/A & N/A & N/A & N/A & N/A \\
\hline
\end{tabular}

Table 4. Percentages of students who did not complete a certain HydroViz module.

\begin{tabular}{|c|c|c|c|c|c|c|c|c|c|}
\hline & $\begin{array}{l}\text { Watersheds } \\
\text { and sub- } \\
\text { watersheds }\end{array}$ & $\begin{array}{l}\text { Land-use } \\
\text { land cover }\end{array}$ & $\begin{array}{l}\text { Soil } \\
\text { type }\end{array}$ & $\begin{array}{c}\text { Land } \\
\text { elevation }\end{array}$ & $\begin{array}{c}\text { Field } \\
\text { equipment }\end{array}$ & $\begin{array}{c}\text { Rainfall } \\
\text { data }\end{array}$ & $\begin{array}{c}\text { Rainfall } \\
\text { measurement } \\
\text { analysis }\end{array}$ & $\begin{array}{c}\text { Measuring } \\
\text { rainfall } \\
\text { using } \\
\text { remote } \\
\text { sensing }\end{array}$ & $\begin{array}{c}\text { Analysis of } \\
\text { stream flow } \\
\text { data }\end{array}$ \\
\hline Average & $10 \%$ & $20 \%$ & $24 \%$ & $24 \%$ & $24 \%$ & $20 \%$ & $32 \%$ & $32 \%$ & $28 \%$ \\
\hline Senior average & $13 \%$ & $21 \%$ & $30 \%$ & $25 \%$ & $22 \%$ & $1 \%$ & $16 \%$ & $13 \%$ & $28 \%$ \\
\hline Freshmen average & $9 \%$ & $20 \%$ & $17 \%$ & $24 \%$ & $25 \%$ & $30 \%$ & $48 \%$ & $41 \%$ & N/A \\
\hline CIVE $429 \mathrm{SP}$ & $10 \%$ & $5 \%$ & $5 \%$ & $6 \%$ & $4 \%$ & $1 \%$ & $10 \%$ & $13 \%$ & $27 \%$ \\
\hline CE 4603 FA & $16 \%$ & $30 \%$ & $30 \%$ & $25 \%$ & N/A & N/A & N/A & N/A & N/A \\
\hline CEE 4420 FA & N/A & $27 \%$ & $55 \%$ & $43 \%$ & $40 \%$ & N/A & $21 \%$ & N/A & $28 \%$ \\
\hline CE $101 \mathrm{SP}$ & $10 \%$ & $26 \%$ & $27 \%$ & $31 \%$ & $41 \%$ & $35 \%$ & $53 \%$ & $47 \%$ & N/A \\
\hline CE $1301 \mathrm{SP}$ & $1 \%$ & $14 \%$ & $8 \%$ & $17 \%$ & $9 \%$ & $25 \%$ & $42 \%$ & $35 \%$ & N/A \\
\hline CE $101 \mathrm{FA}$ & $15 \%$ & $19 \%$ & $17 \%$ & N/A & N/A & N/A & N/A & N/A & N/A \\
\hline
\end{tabular}

indicates that the tool was successful in facilitating students' learning and understanding of hydrologic concepts and related skills. The tool seems to be more effective for students in the senior-level Engineering Hydrology or Water Resource engineering courses. An average of 69-91\% of them showed competency for these concepts. Concepts in the latter modules seem to be more difficult to grasp than those in the other modules. The percentages of students who received full or almost full scores for the last four modules were lower than the previous ones.

Students' completion of an assigned module is another indication of the how much the tool facilitates a certain set of activities. Table 4 shows that an average of 10-32\% of students did not complete certain HydroViz modules assigned by the instructors. Senior students performed better where the highest incompletion rate for a module is $30 \%$, whereas for freshmen, up to $48 \%$ of them did not complete a module. The completion rates for the last three modules are lower than the other ones.

The survey results seem to be consistent with the analysis of homework assignment within each module (Table 5).
Of all participants, an average of $67-87 \%$ of students agreed or strongly agreed that HydroViz contributed to their understanding of the hydrologic concepts. This was particularly true with students in the senior-level courses, in which $78 \%$ $100 \%$ of them strongly agreed or agreed that HydroViz contributed to their understanding of various concepts. Freshmen were less positive. About $52 \%$ to $88 \%$ of the students in freshmen classes from two universities strongly agreed or agreed that HydroViz contributed to their understanding of various concepts. About $81 \%$ of the freshmen strongly agreed or agreed with the following statement: "I found $\mathrm{Hy}$ droViz useful in introducing basic hydrologic concepts."

\subsection{What are students' perceptions of various features and characteristics of HydroViz?}

To answer this question, descriptive statistics were calculated for seven survey items related to this question. Students' comments and informal interview notes were also analyzed to identify ideas and patterns. Students had positive perceptions of various features of HydroViz (Table 6). Of all the participants, 79-93\% strongly agreed or agreed that they 
Table 5. Percentage of students who agree or strongly agree that HydroViz contributed to their understanding of various hydrologic concepts.

\begin{tabular}{|c|c|c|c|c|c|c|c|}
\hline & $\begin{array}{r}\text { Watersheds } \\
\text { and sub- } \\
\text { watersheds }\end{array}$ & $\begin{array}{r}\text { Land-use } \\
\text { and Soil- } \\
\text { type } \\
\text { coverage }\end{array}$ & $\begin{array}{r}\text { Hydrologic } \\
\text { field } \\
\text { sensors }\end{array}$ & $\begin{array}{c}\text { Spatial } \\
\text { variability } \\
\text { of hydrologic } \\
\text { variables }\end{array}$ & $\begin{array}{c}\text { Uncertainty } \\
\text { in measuring } \\
\text { rainfall }\end{array}$ & $\begin{array}{l}\text { Runoff-to- } \\
\text { rainfall } \\
\text { ratio }\end{array}$ & $\begin{array}{l}\text { (Freshmen } \\
\text { only) } \\
\text { Basic } \\
\text { hydrologic } \\
\text { concepts }\end{array}$ \\
\hline Average & $87 \%$ & $84 \%$ & $82 \%$ & $67 \%$ & $76 \%$ & $81 \%$ & $81 \%$ \\
\hline Senior average & $97 \%$ & $96 \%$ & $100 \%$ & $78 \%$ & $82 \%$ & $81 \%$ & N/A \\
\hline Freshmen average & $80 \%$ & $75 \%$ & $70 \%$ & $60 \%$ & $72 \%$ & N/A & $81 \%$ \\
\hline CIVE $429 \mathrm{SP}$ & $100 \%$ & $96 \%$ & $100 \%$ & $82 \%$ & $96 \%$ & $89 \%$ & N/A \\
\hline CE 4603 FA & $91 \%$ & $91 \%$ & N/A & N/A & N/A & N/A & N/A \\
\hline CEE 4420 FA & $100 \%$ & $100 \%$ & $100 \%$ & $73 \%$ & $67 \%$ & $73 \%$ & N/A \\
\hline CIVE $101 \mathrm{SP}$ & $88 \%$ & $75 \%$ & $69 \%$ & $56 \%$ & $88 \%$ & N/A & $87 \%$ \\
\hline CE $1301 \mathrm{SP}$ & $72 \%$ & $72 \%$ & $88 \%$ & $72 \%$ & $72 \%$ & N/A & $74 \%$ \\
\hline CE $1301 \mathrm{FA}$ & $83 \%$ & $76 \%$ & $52 \%$ & $52 \%$ & $57 \%$ & N/A & $78 \%$ \\
\hline CIVE $101 \mathrm{FA}$ & $78 \%$ & $78 \%$ & N/A & N/A & N/A & N/A & $83 \%$ \\
\hline
\end{tabular}

Table 6. Percentages of students who strongly agree or agree that they like various features of HydroViz.

\begin{tabular}{|c|c|c|c|c|c|c|c|}
\hline & $\begin{array}{r}\text { Embedding } \\
\text { Google } \\
\text { Earth }\end{array}$ & $\begin{array}{r}\text { Realistic } \\
\text { representation }\end{array}$ & $\begin{array}{l}\text { Integrated } \\
\text { system }\end{array}$ & $\begin{array}{r}\text { Interact } \\
\text { with } \\
\text { HydroViz } \\
\text { to extract } \\
\text { data }\end{array}$ & $\begin{array}{c}\text { Questions are } \\
\text { integrated with } \\
\text { Google Earth }\end{array}$ & $\begin{array}{c}\text { Data and } \\
\text { modeling } \\
\text { skills are } \\
\text { not required }\end{array}$ & $\begin{array}{l}\text { Encouraging } \\
\text { independent } \\
\text { exploration }\end{array}$ \\
\hline Overall average & $91 \%$ & $93 \%$ & $89 \%$ & $86 \%$ & $80 \%$ & $79 \%$ & $83 \%$ \\
\hline Senior average & $96 \%$ & $97 \%$ & $93 \%$ & $95 \%$ & $83 \%$ & $86 \%$ & $88 \%$ \\
\hline Freshmen average & $87 \%$ & $90 \%$ & $86 \%$ & $79 \%$ & $79 \%$ & $75 \%$ & $79 \%$ \\
\hline CIVE $429 \mathrm{SP}$ & $96 \%$ & $100 \%$ & $96 \%$ & $100 \%$ & $86 \%$ & $86 \%$ & $100 \%$ \\
\hline CE 4603 FA & $91 \%$ & $91 \%$ & $91 \%$ & $91 \%$ & $82 \%$ & $91 \%$ & $91 \%$ \\
\hline CEE 4420 FA & $100 \%$ & $100 \%$ & $93 \%$ & $93 \%$ & $80 \%$ & $80 \%$ & $73 \%$ \\
\hline CIVE $101 \mathrm{SP}$ & $94 \%$ & $100 \%$ & $88 \%$ & $75 \%$ & $69 \%$ & $69 \%$ & $75 \%$ \\
\hline CE $1301 \mathrm{SP}$ & $76 \%$ & $76 \%$ & $80 \%$ & $80 \%$ & $72 \%$ & $64 \%$ & $76 \%$ \\
\hline CE $1301 \mathrm{FA}$ & $85 \%$ & $88 \%$ & $88 \%$ & $82 \%$ & $91 \%$ & $82 \%$ & $85 \%$ \\
\hline CIVE $101 \mathrm{FA}$ & $94 \%$ & $94 \%$ & $89 \%$ & $78 \%$ & $83 \%$ & $83 \%$ & $78 \%$ \\
\hline
\end{tabular}

liked the various features and characteristics of HydroViz shown in Table 6. Students in the senior-level courses were slightly more positive. In these courses, the percentage of students who strongly agreed or agreed that they liked various features of the tool ranged from $83 \%$ to $97 \%$, yet the percentage of students in the freshmen course who strongly agree or agree that they like various features of the tool range from 75-90\%. Students commented that they like the tool because it is hands-on and it presents the technical subject within a real-world context.

\subsection{What are students' perceptions of HydroViz as a part of the curriculum?}

Descriptive statistics for two survey items related to this question were calculated and analyzed along with related students' comments and informal interview notes. Overall, students have positive perceptions of HydroViz as a part of the curriculum (Table 7). About $85 \%$ of the students in the senior-level courses strongly agreed or agreed with the following statement: "I find that HydroViz improves on current teaching tools/methods typically used in hydrologic engineering courses." Almost all of them (96\%) strongly agreed or agreed that HydroViz fits well with the curriculum. The freshmen in the civil engineering introduction course found the tool less relevant. About $63 \%$ of them strongly agreed or agreed that HydroViz fits well with the curriculum.

\subsection{How effective is the HydroViz software in developing freshmen engineering students' interest in hydrology as a subject area?}

To answer this question, statistics of two survey items and other related students' comments and informal interview notes were analyzed. The results indicated that a little over half of the freshmen civil engineering students believed that the experience with HydroViz raised their interest in hydrology (Table 7). About $57 \%$ of the freshmen strongly agreed 
Table 7. Percentages of students who strongly agree or agree with some statements in the survey.

\begin{tabular}{lccr}
\hline & $\begin{array}{c}\text { (Seniors only) } \\
\text { HydroViz } \\
\text { improves } \\
\text { current } \\
\text { teaching } \\
\text { methods in }\end{array}$ & $\begin{array}{c}\text { (Freshmen only) } \\
\text { HydroViz } \\
\text { increases my } \\
\text { enthusiasm for } \\
\text { the subject } \\
\text { of hydrology }\end{array}$ & $\begin{array}{r}\text { (All students) } \\
\text { HydroViz } \\
\text { fits well } \\
\text { into the } \\
\text { curriculum of } \\
\text { this course }\end{array}$ \\
& hydrologic & & \\
courses & & & \\
Overall average & $85 \%$ & $57 \%$ & $78 \%$ \\
Senior average & $85 \%$ & N/A & $96 \%$ \\
Freshmen average & N/A & $57 \%$ & $96 \%$ \\
CIVE 429 SP & $96 \%$ & N/A & $91 \%$ \\
CE 4603 FA & $73 \%$ & N/A & $100 \%$ \\
CEE 4420 FA & $87 \%$ & N/A & $63 \%$ \\
CIVE 101 SP & N/A & $63 \%$ & $52 \%$ \\
CE 1301 SP & N/A & $46 \%$ & $76 \%$ \\
CE 1301 FA & N/A & $59 \%$ & $67 \%$ \\
CIVE 101 FA & N/A & $61 \%$ & \\
\hline
\end{tabular}

or agreed with this statement: "As a new freshmen civil engineering student, I found HydroViz useful in increasing my enthusiasm for the subject of hydrology." Several freshmen civil engineering students commented that the tool was eye opening for them.

\subsection{Do students in different classes and universities differ in their learning of the hydrologic concepts and perceptions of HydroViz?}

To answer this question, descriptive statistics were calculated and analyzed for all survey items answered by students. In Tables 3-7, it is clear that in general, students in senior level classes received better scores and had higher completion rates for HydroViz homework assignments and reported more positive perceptions of HydroViz than students in freshmen classes. There does not seem to be obvious differences between different universities.

\subsection{What can be done to improve HydroViz?}

Based on analysis of students' comments and informal interview notes, students identified some issues that can be addressed to improve HydroViz. Many students commented on the heavy workload in each task and indicated that they could enjoy the project more if they had more time. Table 4 shows that the average percentages of students who did not complete the tasks increased for the last several sections of the assignments. Students suggested that the instructor should introduce HydroViz early on in the semester and present the course modules in incremental chunks to be used as companions to the course subjects throughout the semester. In addition, the tool should include indication of the scope of the project, including the total numbers of screens and tasks as well as their current progress in completing the tasks.
Further, students suggested that the tool allow the user to jump or navigate to a certain screen or module without having to go through every one.

Some freshmen did not think that the content was particularly relevant to their specific engineering field. Some of them thought that the project was too long and challenging for them. A simplified version of HydroViz might be more appropriate for this group of students. One suggestion was that the tool include a demo that shows the overall functionality of HydroViz with some examples of the activities and expected results/outcomes. One of the challenges for some students was the required use of Excel in the assignment. Instructions on how to graph in Excel would be helpful to these students. The tasks for the last few set of questions seemed to be particularly challenging. More guidance or instructions might be needed to improve students' learning.

\section{Conclusions and recommendations for design principles}

HydroViz was designed as a Web-based, student-centered, educational tool to support active learning in the field of Engineering Hydrology. The development of HydroViz targets three main outcomes: (1) facilitating students' learning and understanding of basic hydrologic concepts and increasing related observational and data analysis skills, (2) development of hydrology course modules that are adaptable and transferable to other institutions, and (3) development of improved knowledge on how Web-based techniques for geospatial navigation, visualization and data publication and analysis can be used to improve undergraduate hydrology education.

Design-based research (Reeves, 2000; Design-Based Research Collective, 2003) provided a framework for this project. One of the goals of design-based research is to generate design guidelines and principles to inform future projects. The development and evaluation conducted in this study revealed some lessons that can guide further enhancement of HydroViz, but more importantly contribute to the development of other active learning hydrology educational systems. The following is a set of design principles that were identified and developed based on the current study.

\subsection{Principle 1}

The hydrology education community should consider taking a case-based, data-driven approach that focuses on visualization and simulation in developing hydrology educational systems. This approach was adopted in HydroViz. The modules in HydroViz are embedded in a data and simulation-rich case study of a real-world hydrologic system (e.g., a watershed in a specific location). The real-world context, and the use of Web-based resources (e.g., Google Earth) that are familiar to students, made the learning meaningful and interesting to 
students. This finding is not surprising. It is consistent with the theories and research on how case-based learning and simulation enhance learning (e.g., Kolodner, 1993).

\subsection{Principle 2}

When developing hydrology education software, considerations should be given to make the technical implementation of the software easy. HydroViz was developed as a Webbased tool that can run on any Web browser. The only requirement is to download a free Google Earth (GE) Web browser plug-in. This minimal hardware and software requirement made it easy to disseminate HydroViz to other independent institutions that were not involved in the software development process. This principle is supported by Rogers' (2003) theory of Diffusion of Innovation, which identifies five intrinsic characteristics of innovations that impact the rate of adoption. One of the characteristics relates to complexity. It is easier for a program to be adopted if it is designed in a way that complexity in adopting the programs is reduced for users.

\subsection{Principle 3}

An easy-to-use interface and guidance for learners to complete the tasks should be provided when developing hydrology education software to make it easy for users. For example, in HydroViz, the instructions and tasks are included in the same screens that show the different watershed Google Earth layers. This is consistent with the spatial contiguity principle in multimedia learning (Mayer, 2005) that people learn better when related content are presented near rather than far from each other on the page or screen. In addition, the instructional content should be tested with students to clarify the content. For example, in HydroViz, the formative evaluation indicated that some questions needed more clarification, and that some of the activities needed to be broken down to make the modules more focused and to deliver them in smaller chunks. Lower scores and completion rates of the last three or four modules suggested that they were more challenging than other modules. Providing more guidance with the use of video tutorials, templates for data entry, and example solutions might help improve student learning. After this evaluation study, the developing team improved HydroViz by clarifying the questions, providing more guidance, and refining navigation and interface design. These efforts would further improve the effectiveness of the tool so that it could be used successfully with minimum support from the instructor.

\subsection{Principle 4}

Contextual variables such as when and where the software is used should be considered when developing and implementing hydrology education software. This is a common issue with educational innovations (Dede, 2005). A program might prove to be effective in small-scale testing; yet it may not be successful when implemented in other contexts. Typically, contextual variables may contribute to an inconsistent performance. Reducing these variables might lead to more positive results. In our case, the evaluation drew our attention to some contextual variables that we need to communicate to the instructors when the tool is used in other institutions. For example, how and at what stage to use HydroViz was a significant factor that can impact students' performance. In some classes, the tool was introduced toward the end of the semester. Students had very limited time to complete all the activities, which led to negative attitude. In addition, some instructors assigned HydroViz activities without presenting the overriding hydrologic concepts in the class. This might have also negatively impacted the implementation of HydroViz. As such, we believe that Web-based tools such as HydroViz are best used as supplementary materials to existing curriculum of hydrology, rather than as a replacement. As the instructor presents the different hydrologic subjects, HydroViz can be used to provide more hands-on activities and practice. Better integration of the tool into existing hydrology curriculum, rather than using it as an isolated element, will improve student learning. We expect higher scores for the performance tasks if they are included in the grading structure for the class so that more students turn in the assignments. Since the contextual variables may impact the effectiveness of the HydroViz, the development of an Instructor Guide was identified as a critical component that needs to be developed for HydroViz and other similar tools.

\subsection{Principles 5}

Different versions of hydrology education software should be developed to meet the needs of different audiences. In our case, HydroViz was much more effective for students in the senior Engineering Hydrology class rather than the freshmen Introduction to Civil Engineering class. This is not surprising since HydroViz was originally designed for engineering hydrology classes. We suspected that the tool might be somewhat challenging for freshmen engineering students to use, but we wanted to find out whether the tool or part of it could serve as an introduction to hydrology and whether it could attract freshmen to the subject of hydrology. We found that the design features that HydroViz has have great potential for this audience. The tool increased the enthusiasm for half of the freshmen and broadened their understanding of civil engineering. Even though HydroViz was challenging to some freshmen, most of them still learned the key concepts. The evaluation provided suggestions for us to create a simplified version of HydroViz and customize it for freshmen engineering students. Embedding video demos and adding more interactive tasks, but less demanding in terms of students' load, can improve the use of tools like HydroViz to recruit students into the field of hydrology. 


\section{Future work}

The course modules embedded within HydroViz were successfully implemented in senior-level engineering hydrology courses at independent institutions, and their potential for increasing freshmen's interest was tested in introductory civil engineering classes. The evaluation results were rather similar across the three institutions involved in the evaluation. Students in two independent institutions demonstrate similar level of learning of the hydrologic concepts and perceptions of HydroViz as compared to students in the university where the tool was originally developed. This indicates that it is quite promising to disseminate HydroViz and use it in engineering hydrology courses in other institutions. The pilot implementation of HydroViz has resulted in an adaptation case by an independent institution which adapted HydroViz design and functionality and developed a completely new application for one of their own local watersheds. The results of this ongoing experiment will provide important feedback on how to enhance and facilitate the adaptability of future expanded versions of HydroViz. The authors are inviting other interested users of HydroViz to participate in potential adoption and adaptation testing studies. The development codes that were used to develop HydroViz are available upon request from the authors and can be customized to develop parallel HydroViz versions for other specific applications.

The authors believe that the results of the current evaluation study will guide future development of HydroViz and other similar tools for hydrology and water resource education. The overall lessons learned from this research indicate that educational developments that are based on embedding the scientific content within a real-world physical context, such as that illustrated in HydroViz, have a great potential for transforming the education of hydrology and for inspiring future generations of hydrologic researchers and practitioners. The authors, in collaboration with educators and researchers from other universities, are currently working on developing an expanded version of HydroViz that will cover three largescale ecosystems (Coastal Louisiana, South Florida and the Everglades, and the Great Salt Lake basin in Utah). Each of these systems will be embedded into a HydroViz-like design to be used as case-based student-centered learning environments that present unique hydrologic concepts and physical settings.

Acknowledgements. Support for this work was provided by the National Science Foundation's Course, Curriculum, and Laboratory Improvement (CCLI) program under Award No. DUE-0737073, and by the National Science Foundation's Transforming Undergraduate Education in Science, Technology, Engineering and Mathematics (TUES) program under Award No. DUE-1122898. The authors acknowledge the participation of students at the University of Louisiana at Lafayette, the University of Texas at San Antonio and Tennessee Technological University for their contribution towards evaluation and improvement of the HydroViz tool.

Edited by: J. Seibert

\section{References}

AghaKouchak, A. and Habib, E.: Application of a Conceptual Hydrologic Model in Teaching Hydrologic Processes, Int. J. Eng. Educ., 26, 963-973, 2010.

AghaKouchak, A., Nakhjiri, N., and Habib, E.: An educational model for ensemble streamflow simulation and uncertainty analysis, Hydrol. Earth Syst. Sci. Discuss., 9, 7297-7315, doi:10.5194/hessd-9-7297-2012, 2012.

Beven, K. J.: Rainfall-runoff modelling: the primer, Wiley, Chichester, 2001.

Bourget, P. G.: Integrated water resources management curriculum in the United States: Results of a recent survey, J. Contemp. Water Res. Educ., 135, 107-114, 2006.

Chatterji, M.: Evidence on "what works": An argument for extended-term mixed-method (ETMM) evaluation designs, Educ. Res., 34, 14-24, 2005.

CUAHSI: Water in a Dynamic Planet: A Five-year Strategic Plan for Water Science, CUAHSI, Washington, D.C., doi:10.4211/sciplan.200711, 2010.

Cunningham, S.: Visualization in Science Education, in: Invention and Impact: Building Excellence in Undergraduate STEM Education, edited by: Cunningham, S., National Science Foundation, Washington, D.C., 141-145, 2005.

de Jong, T. and Van Joolingen, W. R.: Scientific discovery learning with computer simulations of conceptual domains, Rev. Educ. Res., 68, 179-202, 1998.

Dede, C.: Why design-based research is both important and difficult, Educ. Technol., 45, 5-8, 2005.

Design-Based Research Collective: Design-based research: An emerging paradigm for educational inquiry, Educ. Res., 32, 58, 2003.

Dochy, F., Segers, M., Van den Bossche, P., and Gijbels, D.: Effects of Problem-Based Learning: A Meta-Analysis, Learning Instruct., 13, 553-568, 2003.

Downer, C. W. and Ogden, F. L.: GSSHA: Model to Simulate Diverse Stream Flow Producing Processes, J. Hydrol. Eng.-ASCE, 9, 161-174, 2004.

Gallucci, K.: Learning concepts with cases, J. College Sci. Teach., 36, 16-20, 2006.

Habib, E. and Meselhe, E. A.: Stage-discharge relations for lowgradient tidal streams using data-driven models, J. Hydraul. Eng., 132, 482-492, 2006.

Habib, E., Malakpet, C. G., Tokay, A., and Kucera , P. A.: Sensitivity of streamflow simulations to temporal variability and estimation of Z-R relationships, J. Hydrol. Eng.-ASCE , 13, 11771186, 2008.

Habib, E., Larson, B., and Graschel, J.: Validation of NEXRAD multisensor precipitation estimates using an experimental dense rain gauge network in south Louisiana, J. Hydrol., 373, 463-478, 2009.

Howe, C. W. (Ed.): A Creative Critique of U.S. Water Education, J. Contemp. Water Res. Educ., 139, 1-2, 2008.

Joyce, R. J., Janowiak, J. E., Arkin, P. A., and Xie, P. P.: CMORPH: a method that produces global precipitation estimates from passive microwave and infrared data at high spatial and temporal resolution, J. Hydrometeorol., 5, 487-503, 2004.

Kolodner, J. L.: Case-based reasoning, Morgan Kaufmann, San Mateo, CA, 1993. 
Ledley, T. S., Prakash, A., Manduca, C. A., and Fox, S.: Recommendations for making geoscience data accessible and usable in education, EOS, 89(32), 291, 2008.

Libarkin, J. C. and Brick, C.: Research methodologies in science education: visualization and the geosciences, J. Geosci. Educ., 50, 449-455, 2002.

Loucks, D. P.: Educating Future Water Resources Managers, J. Contemp. Water Res. Educ., 139, 17-22, doi:10.1111/j.1936704X.2008.00014.x, 2008.

MacDonald, L. H.: Developing a field component in hydrologic education, Water Resour. Bull., 29, 357-368, 1993.

Mayer, R. (Ed.): The Cambridge handbook of multimedia learning, Cambridge University Press, New York, 2005.

McGrath, M. B. and Brown, J. R.: Visual Learning for Science and Engineering, IEEE Comput. Graph. Appl., 25, 56-63, 2005.

Merwade, V. and Ruddell, B. L.: Moving university hydrology education forward with community-based geoinformatics, data and modeling resources, Hydrol. Earth Syst. Sci., 16, 2393-2404, doi:10.5194/hess-16-2393-2012, 2012.

Miles, M. B. and Huberman, A. M.: Qualitative data analysis: An expanded source book, 2nd Edn., Sage Publications, Thousand Oaks, CA, 1994.

Nash, J. E., Eagleson, P. S., Phillip, J. R., and van der Molen, W. H.: The education of hydrologists (Report of the IAHS-UNESCO Panel), Hydrolog. Sci. J., 35, 597-607, 1990.

Ngambeki, I., Thompson, S. E., Troch, P. A., Sivapalan, M., and Evangelou, D.: Engaging the students of today and preparing the catchment hydrologists of tomorrow: student-centered approaches in hydrology education, Hydrol. Earth Syst. Sci. Discuss., 9, 707-740, doi:10.5194/hessd-9-707-2012, 2012.
NRC - National Research Council: Opportunities in the Hydrologic Sciences, National Academy Press, Washington, D.C., p. 348, 1991.

Posavac, E. J. and Carey, R. G.: Program evaluation: methods and case studies, 6th Edn., Prentice Hall, Upper Saddle River, NJ, 2003.

Ramasundaram, V., Grunwald, S., Mangeot, A., Comerford, N. B., and Bliss, C. M.: Development of an environmental virtual field laboratory, J. Comput. Educ., 45, 21-34, 2005.

Reeves, T. C.:Enhancing the worth of instructional technology research through "design experiments" and other development research strategies, Paper presented at the American Educational Research Association, New Orleans, LA, 2000.

Rogers, E. M.: Diffusion of innovations, 5th Edn., Free Press, New York, NY, 2003.

Seibert, J. and Vis, M. J. P.: Teaching hydrological modeling with a user-friendly catchment-runoff-model software package, Hydrol. Earth Syst. Sci. Discuss., 9, 5905-5930, doi:10.5194/hessd9-5905-2012, 2012.

Wagener, T., Weiler, M., McGlynn, B., Gooseff, M., Meixner, T., Marshall, L., McGuire, K., and McHale, M.: Taking the pulse of hydrology education, Hydrol. Process., 21, 1789-1792, 2007.

Wiggins, G. and McTighe, J.: Understanding by design, Association for Supervision and Curriculum Development, Alexandria, VA, 1998.

Yadav, A. and Beckerman, J. L.: Implementing case studies in a plant pathology course: Impact on student learning and engagement, J. Nat. Resour. Life Sci. Educ., 38, 50-55, 2009. 